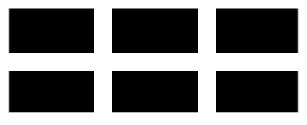

ThE William DAVIDSON INSTITUTE AT THE UNIVERSITY OF MICHIGAN BUSINESS SCHOOL

\title{
Does Economic Uncertainty Affect the Decision to Bear Children? Evidence from East and West Germany
}

\author{
By: Sumon Kumar Bhaumik and Jeffrey B. Nugent
}

William Davidson Institute Working Paper Number 788 August 2005 


\title{
Does Economic Uncertainty Affect the Decision to Bear Children? Evidence from East and West Germany*
}

\author{
Sumon Kumar Bhaumik \\ Brunel Business School, and \\ William Davidson Institute, Ann Arbor, Michigan \\ Jeffrey B. Nugent ${ }^{* *}$ \\ University of Southern California
}

August 15, 2005

\begin{abstract}
:
Although economic agents routinely face various types of economic uncertainty, their effects are often unclear and hard to assess, in part due to the absence of suitable measures of uncertainty. Because of the numerous and very substantial institutional changes that people in the transition economies of Central and Eastern Europe experienced during the last two decades, these countries are excellent candidates for examining the effects of uncertainties on various kinds of behavior. During their periods of uncertainty, moreover, these countries have experienced sharply falling fertility rates. Some have argued that these two phenomena are linked but others have remained skeptical in view of the fact that the evidence is largely confined to the macro level. This paper demonstrates the existence of such a link at the micro level using two different types of uncertainty measures based on GSOEP data from Eastern (and for comparison purposes also Western) Germany for the years 1992-2002. The results suggest that employment uncertainty (but not financial uncertainty) was considerably greater in Eastern Germany during its transition than in Western Germany and had a highly nonlinear effect on the probability of a birth in any period. The result is rather robust to differences in specification and suggests that the higher employment uncertainty in East Germany in the transition could have contributed significantly to the sharp fall and unusually low level of its fertility. In view of the results, we argue that an options based theory is perhaps a richer analytical paradigm for a discussion of fertility decisions in a rapidly changing environment than the traditional Beckerian theory.
\end{abstract}

Keywords: Falling Fertility, Uncertainty, Germany

JEL codes: J13, J22, D81

\footnotetext{
* The authors would like to thank T. Paul Schultz, David Canning, Michaela Kreyenfeld and participants at the 2002 annual conference of the Population Association of America for helpful comments, and DIW (Berlin) for the use of the GSOEP data. They remain responsible for all remaining errors.

** Corresponding author. Address: Department of Economics, University of Southern California, University Park, Los Angeles, CA 90089-0253, USA. Phone: +1 213-740-2107. Fax: +1 213-740-8543. Email: nugent@usc.edu.
} 


\section{Introduction}

In the development literature the relationship between uncertainty and fertility has received considerable attention, but primarily with respect to long-term uncertainties concerning disability and mortality. In this context, it was argued that when uncertainty is modest as in developed countries, there might be little need for many children, but when uncertainty is great as in rural areas of developing countries, its effect on fertility could be positive as long as help from children would be perceived to reduce these uncertainties (Leibenstein, 1957, 1978; Cain, 1980, 1981; Nugent, 1985). For some uncertainties, e.g., about infant mortality, the effects of greater uncertainty were deemed nonlinear. As insurance markets and other means of reducing risks have developed and the risks themselves declined, however, interest in such long-run uncertainties has dissipated.

But, with financial crises, major economic reforms and contagion effects across countries on the rise, short and medium-term uncertainties would seem to be proliferating. With the possible exception of civil wars, disease epidemics and violence, much less attention has been given to the effects of these uncertainties on fertility, often because of the dearth of adequate measures thereof. The evidence that has been provided on the relationship has often been inconsistent. For example, Kohler and Kohler (2002) noted that the early transition period in Russia was characterized by a negative relationship between uncertainty and fertility at the macro level but often by a positive one at the micro level. It is our view that some of these seeming inconsistencies may be due to non-linearities in the relationship between fertility and these short and medium-term uncertainties as well as lack of care in distinguishing between probabilities of various undesired events and uncertainty.

Such worrisome probabilities and uncertainties have been especially prominent in the transition economies of Central and Eastern Europe where numerous different institutional arrangements changed substantially in the 1990s and the planned economy has yielded to a more market-based one. Eastern Germany (the former German Democratic Republic) is an important example and one in which fortuitously various kinds of short to medium term worries or uncertainties have been measured and been found to be quite substantial. Notably, Witte and Wagner (1995) used data from the German SocioEconomic Panel (GSOEP) for the years 1990 through 1992 to show that (1) fairly substantial percentages of women of child-bearing age were concerned with such uncertainties, and (2) those women with concerns for their personal economic situation had lower probabilities of having any, but especially a first, birth after unification than before when these concerns would have been much weaker. Although, quite naturally, the extent of such concerns varied considerably across the population and the sample, they did not control for other factors that would likely affect fertility. Also, given the early date of this innovative study, its authors were unable to examine the experience since the middle of 1992. 
Another relatively early study suggesting the relevance of increased economic uncertainty to the fertility decline in Eastern Germany is Adler (1997). This study placed emphasis on the rise of female unemployment in Eastern Germany and the decline of child and maternal support from the state, both contributing to increased financial uncertainty. Adler, however, did not make use of micro-level data on either uncertainty or fertility, suggesting instead that the aggregate relation between the rising economic uncertainty and falling fertility was due to collective behaviour resulting from either a new survival culture of abstinence from marriage and childbirth or a kind of social protest against the institutional changes lowering women's independence and security.

Additional studies have shown that the pre-1992 decline in East German fertility to well below replacement levels was maintained for at least a few additional years (Conrad, Lechner and Werner, 1996; Lechner, 1998, 2001; Kreyenfeld, 2000; Sobotka, 2002). Indeed, the 1995 total fertility rate for Eastern Germany of 0.8 reported in Lechner (2001) seems to have been the lowest in Europe and perhaps the world at that time. While considerable controversy has arisen over both whether this fall was only temporary (based on spacing) or permanent and whether it was due to the rise in uncertainty or to other factors like convergence in tastes and environmental conditions to those of Western Germany, these issues have not been fully resolved.

Several studies have examined the parallel declines in fertility in other Central and Eastern European countries during the transition (e.g., Sobotka, Zeman and Kantorova, 2003; Kohler and Kohler, 2002, Chase, 2003, and Philipov, Speder and Billari, 2004). While economic uncertainty is mentioned in most of these studies as a possible explanation for the fertility declines, Chase (2003) for the Czech Republic and Slovakia is the only one to actually test for the effect of an uncertainty measure with microlevel data. His measure of employment uncertainty, however, was a dummy variable for having changed jobs in the four years prior to the study. Since one can easily conceive of circumstances in which someone who had changed jobs might have less uncertainty than someone who had not changed jobs, his employment uncertainty measure left much to be desired.

In this study we make use of the same GSOEP surveys for Eastern Germany that have been used in some of the aforementioned studies but for the entire post-reunification period 1992-2002 for which the data are available. In addition, for comparison purposes, we make use of the West German data for the 1984-1991 and 1992-2002 periods. To examine possible nonlinearities in the relationship between unemployment and other worries (or uncertainties) and fertility decisions, instead of a mere dummy variable, we construct indexes of probabilities (and related uncertainties) not only for "personal economic (financial) uncertainty" as used primarily in the preceding studies but also for employment uncertainty. In line with the suggestions of Sobotka (2002), we also control for the various other individual and household characteristics that would seem relevant to fertility. 
Our primary objective is to use this micro-level data to compare the predictions of an uncertaintybased options theory of fertility with those of the traditional neoclassical one in which such worries and uncertainties do not play a role. Other questions that we attempt to address are: (1) Which kind of worry or uncertainty has the largest impact on fertility? (2) For which partner (male or female) do such worries or uncertainties matter most? (3) How do worries about unemployment and finances map into uncertainty measures and what are the directions of such effects? (4) How do the results for Western Germany compare with those for Eastern Germany? (5) Is there any detectible difference in the effects of the worries and uncertainty on the probability of childbirth in West Germany between the pre- and postunification periods? (6) To what extent have the greater unemployment probabilities (and related uncertainties) of the post-unification period contributed to the observed falling fertility rates at the macro level in East Germany?

The remainder of the paper is organized as follows: Section 2 presents alternative ways of thinking of the relationship between uncertainty and fertility decisions. Section 3 presents the data and some descriptive statistics, Section 4 the empirical results and Section 5 our conclusions.

\section{The Decision to Bear Children}

The traditional economic (neoclassical) theory of fertility does not explicitly include uncertainty. In it the demand for fertility is determined by wealth, the opportunity cost of children, and tastes, the latter considered to be given and changing only very slowly. The two most obvious of these factors to change in the transition countries, thus, were the opportunity cost of children and wealth. Since few households had accumulated much financial wealth prior to transition, the major source of wealth was human capital. Hence, while financial uncertainty may not have changed much or been very relevant in transition economies, employment uncertainty could have changed quite significantly and been important in decision-making because of its importance for human wealth.

With respect to the opportunity costs of children, since wage rates rose and the direct costs of having and caring for children increased, in a simple traditional model this would suggest a decline in the number of children. But, in a more general Beckerian model that allows for quantity-quality substitution (Becker, 1976), this would also imply a rise in quality (proxied by education).

Yet, as Ranjan (1999) noted, in fact education of children also fell in most of these transition countries, leading him to develop an alternative theoretical model in which uncertainty about future income leads people to choose an "option" to postpone investments in both the quantity and quality of children until such time as uncertainty would fall. Following Dixit and Pindyck (1994) and the financial option literature, the option allows individual decision makers to avoid the risk of making the irreversible investment when future income could turn out to be low. 
Notably, however, Ranjan's result hinges crucially on the assumption that the saved monetary cost of having a child would outweigh the lower expected wage and hence lower opportunity cost of time for the decision-maker. Yet, it is our view that the net effect of uncertainty, especially about employment, on the value of the option to postpone childbirth would depend on the degree of uncertainty. If uncertainty is initially low, any given increase in uncertainty may primarily lower wealth and increase the value of the option to delay or avoid child investment. But, if employment uncertainty was already high (i.e., and employment prospects sufficiently bad), the opportunity cost element would dominate over the option value of delay so childbirth would become more likely. Also, at higher levels of uncertainty the decisionmaker might well value more the risk-reducing benefit of a child, further raising the likelihood of a positive effect on childbirth. Hence, some increase in uncertainty would raise the child postponement or avoidance option but, beyond some threshold level, a further increase would raise the probability of childbirth.

In slightly more non-standard models, increased wealth can be associated with taste changes that might lower the demand for children. From an option perspective, however, increased wealth should lower the value of the risk-reducing option, thereby raising the demand for children. Similarly, from the neoclassical perspective an increase in a mother's education would increase the potential wage rate and hence raise the opportunity cost of having a child, thereby lowering the likelihood of a birth. But, from the option perspective, the greater mobility that education would allow should reduce vulnerability to risk and the value of the postponement option but should raise the likelihood of a birth.

As a result, it is clear that the neoclassical and option theories of fertility imply quite different behavioral responses to changes in environmental conditions. With appropriate data these alternative models should be testable. Another motivation for examining the uncertainty-based option theory is the interesting but thus far untested claim that it can explain many other forms of household behavior such as savings, family dissolution, and financial portfolios (Drewianka, 2002).

To accomplish the objective of testing the option theory vis-à-vis the neoclassical opportunity cost explanations for childbirth and fertility, we propose the following approach that involves distinguishing between worries about undesired outcomes and uncertainty. For the case of employmentrelated uncertainty, suppose that the probability of being unemployed is defined by the ordered set $\left(\mathrm{p}_{1}, \mathrm{p}_{2}\right.$, $\ldots, \mathrm{p}_{\mathrm{n}}$ ) where $p_{1}$ refers to the lowest probability of being unemployed, while $p_{n}$ refers to the highest probability of being unemployed. In Becker's view, therefore, the likelihood of childbirth would increase monotonically as the probability of unemployment rises from $p_{1}$ to $p_{n}$. Note, however, that employment uncertainty does not increase monotonically from $p_{1}$ to $p_{n}$. When the probability of being unemployed is $p_{1}\left(p_{n}\right)$, for example, the relevant individual is most certain of remaining employed (unemployed). The uncertainty regarding employment, therefore, increases initially as one moves away from $p_{1}$, reaches a 
peak somewhere between $p_{1}$ and $p_{n}$, and then decreases thereafter. In other words, uncertainty $u$ is a non-

linear function of $p_{i}$, i.e., $u=f\left(p_{i}\right)$, and has an inverted-U shape. ${ }^{1}$ Hence, while the traditional opportunity cost theory suggests a monotonically positive effect of such an (un)employment measure on fertility, the options approach suggests that the likelihood of childbirth is inversely related to uncertainty but is related in an U-shaped way to the aforementioned index $p_{i .}$.

It is easily seen that this test is equally applicable to all measures of perceptions of undesired outcomes (or types of uncertainty) that affect human decisions. It is also evident that the success of this empirical exercise might be dependent on the number of states of nature $(n)$ that we can measure using appropriate survey instruments. For example, if we had only a yes/no measure of the probability of unemployment, we would not be able to generate the inverted-U shaped uncertainty curve and thereby to distinguish between the two theoretical models. .

\section{Data}

The data used to carry out such a test was obtained from the aforementioned GSOEP that is collected annually. The first round of the survey was conducted in 1984 and was applied to a sample of 5921 households and individuals in the Federal Republic of Germany (i.e., West Germany). Since then, each year the respondents are asked to respond to questions concerning demographic features, income and social security benefits, education, health and labor market experience, and expectations about the future. Beginning in 1990, however, households in the former German Democratic Republic (East Germany) were included. The sample size of the survey has increased over time, to some 6800 households and 13,000 individuals in recent years (Haisken-Denew and Frick, 2000).

The summary statistics for East and West Germany are reported in Table 1. The data for East Germany corresponds to the 1992-2002 period, while that for West Germany corresponds to the 19842002 period. $^{2}$ For our purposes, we consider only women who are in the childbearing age (18 to 45$)$. It should be noted that the age groups highlighted in the table, namely, 18-30, 31-35, 36-40 and 40-45, are not mutually exclusive, nor do they represent cohorts. For example, if a woman (and hence a household) remains in the sample from 1992 to 1998, and if the woman is 27 years old in 1992, she appears in the 1830 category for the years 1992-95 but in the 31-35 category for 1996-98. Our analysis is not based on cohorts, but, given our objectives, age is one of the key variables determining the balance of cost and benefits of childbearing for a woman in a given year.

\section{INSERT Table 1 about here.}

The descriptive statistics highlight several important aspects of childbearing activity in Germany. First, it is evident that childbirth is a much more likely event for women in the 18-35 age group than for women in the 36-45 age group, in both East and West Germany. However, there are important differences 
in the incidence of childbirth between the women living in the two geographic regions. For all age groups, West German women were much more likely to bear children than East German women. This is consistent with the findings reported above of a precipitous decline in the total fertility rate (TFR) of East German women after German reunification. In particular, while West German women aged 31-35 exhibited a 10 percent incidence of childbirth during the duration of the data, for women of the same age group in Eastern Germany the childbirth rate was less than 2 percent. Since this was for women fairly late in their child-bearing period and the West-East gap was even larger for those in older age groups, this calls into question the hypothesis that postponement was the primary explanation for the sharp decline in East German TFR. ${ }^{3}$

Second, although the average household in both the East and the West was a nuclear household with two adults, for both regions, the average number of adults was higher for households in the 36-40 and especially 41-45 age groups (perhaps because some of the older children of women in such age groups would have entered adulthood). A closer look at the distribution of the adult members across households reveals that nearly 25 percent of East German but under 10 percent of West German households had three or more adults living within the same household. This could imply either that the East German women in our sample had a relatively lower time cost of childbearing or that childbirth resulted in more crowding than those in Western Germany. Further, if the non-partner adult were elderly, the extra time commitment required to take care of this person could make the trade-off between childbearing and employment steeper (Pezzin and Schone, 1998).

Third, East German women are, by and large, more educated than West German women, when education is measured as a categorical variable that captures the level of education relative to primary school. This measure of education is believed to be more meaningful than years of education because of the step (or threshold) function character of the impact of education on lifetime earnings (Pritchett, 2001). However, this does not necessarily suggest that an average East German woman has greater earning potential than an average West German woman since the education obtained in pre-unification East Germany may not fit post-unification skill requirements. Unlike women, sample East German men are not better educated than their West German counterparts.

Fourth, for each age group the size of home of an average West German woman is 6-17 percent larger than that of an average East German woman. Interestingly, the size of home gap is higher for the older age groups than for the younger ones, despite the fact that the number of adults and children residing in an average household is roughly the same for East and West Germany for these age groups. For example, East German households in the 36-40 age group, on average, have 2.34 adults and 1.59 children, while West German ones have 2.12 and 1.56, respectively. Taken together with evidence suggesting that downstream intergenerational transfers play a significant role in determining the size and 
quality of homes of relatively younger couples (Engelhardt and Mayer, 1998), this also suggests that the size of home may serve as at least a crude proxy for the non-human wealth of the household, and is unlikely to be endogenous to childbirth.

Fifth, consistent with aforementioned small role of financial assets in the wealth of East German households, note that, on average, East German women of all age groups were less worried about the financial solvency of their households than West German women. But, as shown below, they had greater reason to worry about employment instead.

Finally and most importantly, we come to the probability of unemployment, and the corresponding employment-related uncertainty index. These are constructed from two questions in the GSOEP questionnaires as explained in the following endnote. ${ }^{4}$ Note that for East Germany, where the unemployment rate throughout the 1990s was nearly double that of West Germany, the average probability of being unemployed was unambiguously higher for both East German men and women than for their West German counterparts. While this probability was similar for Eastern and Western German women in the older age groups, it was much larger for women in the fertility-relevant 18-30 age group and larger for East German men of all age groups. The probability of unemployment was, on average, higher for women than for men, and especially so in Eastern Germany. These results are consistent with both existing literature on the differences in the employment and earnings potential of men and women (Darity and Mason, 1998; Stanley and Jarrell, 1998), and the greater vulnerability of women to unemployment in post-reunification East Germany (Bonin and Euwals, 2001). ${ }^{5}$ Note that it is not possible to say anything very definite about the relative uncertainties of East and West German men and women, given that we do not know the exact functional form that maps unemployment probabilities into uncertainty scores. Nevertheless, since the probabilities are mostly near the middle of the range of possible values, it would appear likely that the differences in unemployment probabilities map into corresponding uncertainty differences.

The descriptive statistics are, by and large, consistent with both general knowledge of German economic conditions, especially East-West differences. In the following section, we turn to the empirical estimates of the relationships between the two types of uncertainty and other factors and the probability of childbirth in East and West Germany.

\section{Estimation Procedure and Results}

Given that the incidence of childbirth in a household is a binary (i.e., birth-no birth) event, and given that we use (unbalanced) panel data, we use a random effects probit model to explain variations across the sample women of the designated age groups in the binary variable childbirth. We assume that in any time period a woman (or a household) simultaneously decides on consumption, time allocation between labor and leisure, the option of bearing a child, and (if relevant) the education of existing children. In this case, 
the optimal responses to all these choices would be functions of exogenous variables like age, and individual (or household) preferences. Given the objective of this paper, however, we focus on the effect of the probabilities of financial distress and unemployment (and hence finance and employment-related uncertainties) on the probability of childbirth alone, after controlling for the exogenous variables identified below.

Our empirical strategy is twofold. First, we estimate random effects probit models for East and West Germany using all the available data for each of these two regions, i.e., 1992-2002 for the East and 1984-2002 for the West. In the estimates of Table 2 we use household characteristics, and age, education, a measure of worry about financial solvency, and the aforementioned probability of unemployment measure of only the woman. In Table 3, we present the corresponding results when education and probability of unemployment of the male partners in the sample are included. Second, we split the data for West Germany into (roughly) the pre- and post-reunification periods, i.e., 1984-91 and 1992-2002, and in Table 4 present the corresponding estimates for Western Germany of the random effects probit models for both sub-periods based on the fuller specification that includes the probability of unemployment for the male partners. This exercise enables us to examine whether or not the environmental changes associated with reunification affected childbirth and provides a direct comparison between East and West German childbirth behavior for the post-reunification period.

In Table 2, we report the marginal effects (estimated at the mean) for both East and West Germany for the periods 1992-2002 and 1984-2002, respectively, based on the specification that excludes the male spouse's characteristics. Explanatory variables include household characteristics like the number of adults and children residing in the household, and age, education, worries about the household's financial solvency, and probability of unemployment of the sample females. ${ }^{6}$ In keeping with existing empirical literature, we model the likelihood of childbirth as a nonlinear function of the woman's age. In the light of the discussion in Section 2 of this paper, it is easy to see why we also model the likelihood of childbirth as a nonlinear function of the probability of unemployment. Since worry about the household's financial solvency may also have a nonlinear mapping into uncertainty, we also use a non-linear specification of this variable. In Table 3, we once again report the marginal effects for East and West Germany, for the same time periods as in Table 2 based on the specification that includes the male spouse's education and probability of unemployment, the latter with the same nonlinearities as in the case of the woman. Finally, in Table 4, we report the marginal effects for West Germany alone, for the 198491 period and the 1992-2002 period based on the Table 3 specification.

Note that the age groups for which the marginal effects are reported in Tables 2-4, namely, 18-30, $18-35,18-40$ and 18-45, are not mutually exclusive. In other words, we do not report the behaviour of women within distinct age groups. Rather, we choose age cut-off points of 30,35, 40 and 45, beyond 
which women would be less and less likely to exercise the choice of bearing a child. Viewed in this light, age cut-offs of 35 and 40 may be viewed as more realistic than ones of 30 and 45 . The latter, however, offers a somewhat larger sample and the former an age group in which childbirth would be more frequent. For completeness, therefore, we report the results obtained using each of these age cut-off points.

INSERT Tables 2 and 3 about here.

The marginal effects for both East and West Germany, as reported in Tables 2 and 3, are remarkably robust to the choice of the age cut-off. The marginal effects reported in Table 2 suggest that age does not influence the exercise of the option (to bear a child) in East Germany. However, the probability of childbirth in the East is negatively affected by numbers of both adults and children in the household. This demonstrates the relevance of the time and other costs of childbearing and shows that the space-related and other costs of sharing a household with other adults outweigh the advantages of additional adults in sharing expenses and childcare. Education of the woman is positively associated with the likelihood of having a child, indicating that the income effect of higher returns on labor dominates the substitution effect arising out of the higher opportunity cost of time. As noted above, this finding is consistent with the options theory and inconsistent with the traditional theory. Finally, while worry about household finance does not matter, perhaps on account of the relatively short (3-point) scale on which this score is measured, the probability of the woman's unemployment does matter (considerably). Further, and again consistent with the options theory and inconsistent with the traditional Beckerian model, the likelihood of childbirth has a U-shaped relationship with this probability.

In West Germany, on the other hand, age matters, and has a non-linear impact on the likelihood of childbearing. As in the East, the number of children in the household has a negative impact on the likelihood of having a child, and the education of the female has a positive impact on this likelihood. However, in the West, the number of household adults does not influence the likelihood of childbearing. Since there are many fewer households in the West with three or more adults, this suggests that space, and the associated coordination cost of sharing space with non-partner adults, may indeed have been a binding constraint in the East. ${ }^{7}$ Further, unlike in the East, the likelihood of bearing a child in West Germany is influenced by the wealth of the household, as measured by the size of the residence. Finally, as in the East, worry about household finances does not matter in the West, but the female's probability of unemployment has the same U-shaped effect on the likelihood of childbearing.

The marginal effects reported in Table 3 indicate that the above results are robust to the inclusion of the male partner's education and his probability of unemployment in the specification. The male partner's education has the expected positive effect on the likelihood of childbearing in West Germany, but it has no impact on this likelihood in East Germany. Further, the unemployment probability of the 
male partner does not seem to have any discernible effect on the decision to bear a child in either East or West Germany.

INSERT Table 4 about here.

Finally, the marginal effects reported in Table 4 indicate that, while the impacts of the household, female and partner characteristics on the likelihood of childbirth are generally preserved when we split the West German sample into two sub-periods - 1984-91 and 1992-2002 - there are some interesting differences in these between periods. In both periods, the likelihood of childbirth increased with the education of the woman and the wealth of the household, and decreased with the number of pre-existing children in the household. Further, in both periods, the age of the female had a quadratic relationship with the likelihood of childbearing. However, while the relationship between a female's probability of unemployment and the likelihood of her bearing a child was U-shaped in the 1992-2002 period, the relationship between these variables was monotonic and positive in the 1984-91 period. In other words, West German women were in a Beckerian world prior to the reunification but an "options" world since then (an issue to which we return below).

\section{Discussion and Concluding Views}

It should be clear from the above that one important objective of the paper has been achieved, namely, to empirically estimate an uncertainty-based options model along the lines of that proposed by Ranjan (1999) and to compare its applicability relative to that of the traditional Beckerian model. In this respect, we find rather strong support for the options-based theory. In terms of the six questions posed at the end of Section 1, our empirical results lead us to the following answers:

First, in terms of the kind of worries about undesired outcomes or uncertainties that seems most important, from Tables 2-4 the results are rather clear in favor of the probability of unemployment. Its effect is considerably stronger and more U-shaped than that of financial worries. Since labor income is the most important source of income for the vast majority of households and employment uncertainty would seem to have increased substantially in East Germany subsequent to reunification, this is not surprising. We should note, however, that the insignificant impact of worry about financial solvency on the likelihood of childbirth could, at least in part, be a consequence of the more limited 3-point scale on which this worry is measured. Conceivably, a finer measure of this worry, mapping on to a better measure of financial uncertainty, could reveal a more significant impact of financial uncertainty on the likelihood of childbirth.

Second, the results of Table 3 make it evident that, even though the directions of the effects of unemployment probabilities on the likelihood of childbirth are quite similar between males and females, it is the female's (i.e., potential mother's) unemployment probability that is more important than the male's 
in reducing fertility. This brings to the fore the increasing role of a second (usually female) partner's income in determining the financial well being of households. But, it is also partially consistent with the Beckerian view about the importance of the female's opportunity cost of time in determining the likelihood of childbirth.

Third, the results reported in Tables 2-4 indicate that, for the period beginning 1992, irrespective of the choice of the terminal age for exercising the option of childbirth, there is evidence of nonlinearities in the effects of the probabilities of unemployment on the probability of childbirth. It is evident from both the magnitudes of the relevant regression coefficients and from Figures 1 and 2 that these nonlinearities are most significant in East Germany where the uncertainties have been somewhat higher and more variable across the sample than in Western Germany. ${ }^{8}$ At the mean of the sample, the magnitudes of the uncertainty measures are such that the net effect of the linear and quadratic terms is negative.

INSERT Figures 1 and 2 about here.

Fourth, even though the signs of the coefficients of the linear and quadratic unemployment probability terms on the probability of childbirth are identical between the East and West German samples and the mean differences in the indexes themselves between regions are quite small, in every case the sensitivity of the probability of childbirth for a woman in East Germany is always greater than the corresponding sensitivity for a woman in West Germany. This greater sensitivity to unemployment worries for East German women would seem very plausible indeed given the fact that labor force participation of East German women had been much higher and as already indicated the institutional circumstances were changing more radically than for West German women. ${ }^{9}$

Fifth, the results of Table 4 show that there were several important changes in the determinants of childbirth in a given year between the pre- and post-unification periods in Western Germany. The agerelated nonlinearities became sharper, indicating that such women tended to postpone childbirth longer after reunification. The presence of other adults in the household tended to have a less positive (or more negative) influence and the presence of other children a more negative effect in the latter period, suggesting that West German women were increasingly not only postponing but also reducing the number of children. The impacts of male and female education changed in opposite directions between the two periods, the positive effect rising for men but falling for women. Most importantly, the effect of unemployment probabilities among females on childbirth probabilities became more sharply nonlinear post-unification than pre-unification. Since there is no evidence to suggest that the historically low rate of labor force participation among West German women had undergone a significant change in the aftermath of the reunification, this sharper nonlinear effect post reunification could be due to greater unease about the sustainability of the social security system in an environment of reunification related 
fiscal pressure on a government bound by the Maastricht agreement on (among other things) the fiscal deficit and public debt.

Finally, to provide at least a crude answer to the last question (concerning the extent to which the increased uncertainty may have contributed to the decline in child births, we conduct the following exercise. While from Table 1 we know the average unemployment probability index for East German women between 18 and 30 was 3.12 in the post-reunification period, we do not know what it was prior to reunification. In view of the pervasiveness of the welfare state and the extremely high employment rate and child support available to East German households prior to unification, we can be sure that it must have been considerably lower. It would seem highly likely that it was below the average for West German women pre-unification (2.53).

Let us suppose, and probably still quite conservatively, that the initial average unemployment probability index was 2.12 . This would imply that, on average, employment uncertainty might have increased a full index point. Using the estimated coefficients for women of the 18-30 age group reported in Table 3 (of -0.69 for the linear term and 0.10 for the quadratic term), for a woman starting with above average unemployment probability index (e.g., of 3) an increase of 1 (to 4) would have almost no effect $(\approx 0.09)$ on the probability of a birth as the effect of the positive quadratic term would almost exactly offset the effect of the negative linear term. ${ }^{10}$ The same increase for a woman with an initially belowaverage unemployment probability index (e.g., from 1.5 to 2.5 ) would exert a modest negative influence of the probability of childbirth $(\approx-0.29)$. At a still higher initial value (e.g., 4$)$, the increase would result in an increase in the probability of childbirth. But for a woman with an exactly average initial (i.e., prereunification) unemployment probability index (assumed to be 2.12), the increase of unity would reduce the probability of childbirth by as about 1.0 !

While these numbers are only suggestive and the perhaps more reliable point estimates from the larger sample of East German women age 18-40 or 18-45, would yield somewhat smaller net effects on childbirth, the calculation makes clear that, given the undoubtedly low starting value of the index, the increase in unemployment probabilities for most East German women, i.e., all except those at the highest pre-unification levels of unemployment uncertainty, could well have contributed substantially to the overall substantial reduction in child births observed at the macro-level. Further, because the net effects would differ across the distribution of women by initial and changed uncertainty indexes, it shows rather clearly why micro and macro level studies may often be inconsistent with each other.

The Beckerian or neoclassical view of fertility decision, which emphasises the role of substitution effect (or opportunity cost of time) in determining the likelihood of childbirth, remains the dominant hypothesis in the demographic literature. However, it is our view that an approach that treats childbirth as an option that a woman can exercise up to some biologically feasible age, one that explicitly models the 
impact of the probability of unwanted outcomes (and related uncertainties) on the decision to bear a child, provides a still richer analytical framework within which the childbearing decision should be discussed.

Beyond this, our analysis and results call attention to the need for greater precision in measuring the probabilities of unwanted outcomes via more detailed survey questions and at the same time greater care in relating these measures to measures of uncertainty. 


\section{References}

Adler, Marina A. 1997. "Social Change and Declines in Marriage and Fertility in Eastern Germany," Journal of Marriage and the Family, 59 (February), 37-49.

Becker, Gary S. 1976. "An Economic Analysis of Fertility," In The Economic Approach to Human Behavior, Chicago: University of Chicago Press, 171-194.

Bonin, Holger and Rob Euwals 2001. "Participation Behaviour of East German Women after Reunification,” Bonn: IZA Discussion Paper No. 413.

Cain, Mead 1980. "Risk, Fertility and Family Planning in a Bangladesh Village," Studies in Family Planning, 11, 219-223.

Cain, Mead 1981. "Risk and Insurance: Perspectives on Fertility and Agrarian Change in India and Bangladesh," Population and Development Review, 7 (3), 435-474.

Chase, Robert S. 2003. "Household Fertility Responses following Communism: Transition in the Czech Republic and Slovakia," Journal of Population Economics, 16(3), 579-595.

Conrad, Christoph, Michael Lechner and Welf Werner 1996. "East German Fertility after Unification: Crisis or Adaptation?" Population and Development Review, 22 (2), 331-358.

Darity, William A. Jr. and Patrick L. Mason 1998. "Evidence of Discrimination in Employment: Codes of Color, Codes of Gender," Journal of Economic Perspectives, 12(2), 63-90.

Dixit, Avinash and Robert S. Pindyck 1994.. Investment Under Uncertainty. Princeton: Princeton University Press.

Drewianka, Scott 2002. "Dual Incomes, Labor Market Uncertainty and Family Structure," Milwaukee, University of Wisconsin-Milwaukee, Economics Working Paper.

Engelhardt, Gary V. and Christopher J. Mayer 1998. "Intergenerational Transfers, Borrowing Constraints, and Savings Behavior: Evidence from the Housing Market," Journal of Urban Economics, 44, 135-157.

Haisken-DeNew, J. P. and J. R. Frick 2000. Desktop Companion to the German Socio-Economic Panel, version 3, Berlin: DIW.

Kohler, Hans-Peter and Iliana Kohler 2002. "Fertility decline in Russia in the Early and Mid 1990s: The Role of Economic Uncertainty and Labour Market Crises," European Journal of Population, 18 (3), 233262.

Kreyenfeld, Michaela 2000. "Employment Careers and the Timing of First Births in East Germany," Rostock: Max Planck Institute for Demographic Research Working Paper 2000-004.

Lechner, Michael 1998. Eine empirische Analyse der Geburtenentwicklung in den neuen Bundesländern, Zeitschrift für Wirtschaft- und Sozialwissenschaften (ZWS), 118, 463-488

Lechner, Michael 2001. "The Empirical Analysis of East German Fertility after Unification: An Update," European Journal of Population 17, 61-74. 
Leibenstein, Harvey 1957. Economic Backwardness and Economic Growth. New York: John Wiley.

Leibenstein, Harvey 1978. General X-Efficiency Theory and Economic Development. London: Oxford University Press.

Lesthaeghe, Ron and Guy Moors 2000. "Recent Trends in Fertility and Household Formation in the Industrialized World," Review of Population and Social Policy, 9, 121-170.

Nugent, Jeffrey B. 1985. "The Old-Age Security Motive for Fertility," Population and Development Review 11 (1), 75-97.

Pezzin, Liliana E and Barbara S. Schone 1998. Intergenerational Household Formation, Female Labor Supply and Informal Care Giving," Journal of Human Resources, 34, 3, 475-503.

Philipov, Dimiter, Zsolt Speder and Francesco Billari 2004. "Fertility Intentions and Their Timing: Theory and Evidence from Bulgaria and Hungary" Paper presented at the 2004 annual meeting of the Population Association of America, http://paa2004.princeton.edu/download.asp?submissionId=40761.

Pritchett, Larry 2001. "Where has all the Education Gone," The World Bank Economic Review, 15(3), 367-91.

Ranjan, Priya 1999. "Fertility Behavior under Income Uncertainty," European Journal of Population, 15, 25-43.

Sobotka, Tomas 2002. "Comments on 'The Empirical Analysis of East German Fertility after Unification: An Update'," European Journal of Population, 18 (4), 429-431.

Sobotka, Tomas, Krystof Zeman and Vladimira Kantorova 2003. "Demographic Shifts in the Czech Republic after 1989: A Second Demographic Transition View," European Journal of Population, 19 (3), 151-213.

Sobotka, Tomas 2004. "Is Lowest-Low Fertility in Europe Explained by the Postponement of Childbearing?" Population and Development Review, 30 (1), 195-220.

Spahn, P., H. Kaiser and T. Kassella 1994. "The Taxation of Married Couples in Germany: Distributive and Allocative Aspects," In M. Eichhorn (Ed.), Models and Measurement of Welfare and Inequality, Berlin: Springer, 361-395.

Stanley, T.D. and Stephen B. Jarrell 1998. "Gender Wage Discrimination Bias? A Meta Regression Analysis,” Journal of Human Resources, 33(4), 947-73.

Strøm, S. and G. Wagenhals 1991. "Female Labour Supply in the Federal Republic," Jahrbücher für Nationalökonomie und Statistik, Vol 208, pp. 575-595.

Witte, James C. and Gert G. Wagner 1995. "Declining Fertility in East Germany after Unification: A Demographic Response to Socioeconomic Change," Population and Development Review 21 (June), 387397. 
Table 1

Descriptive statistics for Samples of East and West German Women of Specified Age Groups

\begin{tabular}{|c|c|c|c|c|c|c|c|c|}
\hline & \multicolumn{2}{|c|}{$18-30$} & \multicolumn{2}{|c|}{$31-35$} & \multicolumn{2}{|c|}{$36-40$} & \multicolumn{2}{|c|}{$40-45$} \\
\hline & East & West & East & West & East & West & East & West \\
\hline $\begin{array}{l}\text { Childbirth } \\
\text { incidence }\end{array}$ & $\begin{array}{l}0.08 \\
(0.27)\end{array}$ & $\begin{array}{l}0.18 \\
(0.39)\end{array}$ & $\begin{array}{l}0.018 \\
(0.13)\end{array}$ & $\begin{array}{l}0.10 \\
(0.31)\end{array}$ & $\begin{array}{l}0.002 \\
(0.04)\end{array}$ & $\begin{array}{l}0.03 \\
(0.18)\end{array}$ & $\begin{array}{l}0.003 \\
(0.05)\end{array}$ & $\begin{array}{l}0.006 \\
(\odot .07)\end{array}$ \\
\hline Age (f) & $\begin{array}{l}28.06 \\
(1.88)\end{array}$ & $\begin{array}{l}28.46 \\
(2.74)\end{array}$ & $\begin{array}{l}33.27 \\
(1.36)\end{array}$ & $\begin{array}{l}33.00 \\
(1.40)\end{array}$ & $\begin{array}{l}38.02 \\
(1.40)\end{array}$ & $\begin{array}{l}37.87 \\
(1.41)\end{array}$ & $\begin{array}{l}42.49 \\
(1.13)\end{array}$ & $\begin{array}{l}42.38 \\
(1.09)\end{array}$ \\
\hline Household adults & $\begin{array}{l}2.05 \\
(0.22)\end{array}$ & $\begin{array}{l}2.00 \\
(0.08)\end{array}$ & $\begin{array}{l}2.05 \\
(0.31)\end{array}$ & $\begin{array}{l}2.01 \\
(0.13)\end{array}$ & $\begin{array}{l}2.34 \\
(0.59)\end{array}$ & $\begin{array}{l}2.12 \\
(0.38)\end{array}$ & $\begin{array}{l}2.85 \\
(0.72)\end{array}$ & $\begin{array}{l}2.49 \\
(0.70)\end{array}$ \\
\hline $\begin{array}{l}\text { Household } \\
\text { children }\end{array}$ & $\begin{array}{l}1.60 \\
(0.67)\end{array}$ & $\begin{array}{l}0.77 \\
(0.91)\end{array}$ & $\begin{array}{l}1.82 \\
(0.73)\end{array}$ & $\begin{array}{l}1.48 \\
(1.03)\end{array}$ & $\begin{array}{l}1.59 \\
(0.85)\end{array}$ & $\begin{array}{l}1.56 \\
(1.03)\end{array}$ & $\begin{array}{l}0.89 \\
(0.81)\end{array}$ & $\begin{array}{l}0.98 \\
(0.97)\end{array}$ \\
\hline Education ( $f$ ) & $\begin{array}{l}2.06 \\
(0.29)\end{array}$ & $\begin{array}{l}1.96 \\
(0.55)\end{array}$ & $\begin{array}{l}2.10 \\
(0.38)\end{array}$ & $\begin{array}{l}2.04 \\
(0.58)\end{array}$ & $\begin{array}{l}2.16 \\
(0.41)\end{array}$ & $\begin{array}{l}2.03 \\
(0.60)\end{array}$ & $\begin{array}{l}2.12 \\
(0.44)\end{array}$ & $\begin{array}{l}1.97 \\
(0.62)\end{array}$ \\
\hline Size of home & $\begin{array}{l}82.90 \\
(35.67)\end{array}$ & $\begin{array}{l}88.52 \\
(33.09)\end{array}$ & $\begin{array}{l}88.27 \\
(31.56)\end{array}$ & $\begin{array}{l}105.36 \\
(34.40) \\
\end{array}$ & $\begin{array}{l}93.93 \\
(30.42) \\
\end{array}$ & $\begin{array}{l}113.14 \\
(36.94) \\
\end{array}$ & $\begin{array}{l}93.65 \\
(32.80)\end{array}$ & $\begin{array}{l}113.90 \\
(38.61) \\
\end{array}$ \\
\hline $\begin{array}{l}\text { Worries about } \\
\text { finance ( } f \text { ) }\end{array}$ & $\begin{array}{l}1.80 \\
(0.59)\end{array}$ & $\begin{array}{l}2.17 \\
(0.64)\end{array}$ & $\begin{array}{l}1.90 \\
(0.58)\end{array}$ & $\begin{array}{l}2.23 \\
(0.65)\end{array}$ & $\begin{array}{l}1.81 \\
(0.58)\end{array}$ & $\begin{array}{l}2.27 \\
(0.65)\end{array}$ & $\begin{array}{l}1.88 \\
(0.57)\end{array}$ & $\begin{array}{l}2.27 \\
(0.64)\end{array}$ \\
\hline $\begin{array}{l}\text { Probability of } \\
\text { Unemployment }(f)\end{array}$ & $\begin{array}{l}3.12 \\
(1.60)\end{array}$ & $\begin{array}{l}2.50 \\
(1.70)\end{array}$ & $\begin{array}{l}2.64 \\
(1.54)\end{array}$ & $\begin{array}{l}2.71 \\
(1.80)\end{array}$ & $\begin{array}{l}2.58 \\
(1.47)\end{array}$ & $\begin{array}{l}2.58 \\
(1.80)\end{array}$ & $\begin{array}{l}2.50 \\
(1.51)\end{array}$ & $\begin{array}{l}2.51 \\
(1.83)\end{array}$ \\
\hline Education (m) & $\begin{array}{l}2.13 \\
(0.34)\end{array}$ & $\begin{array}{l}2.06 \\
(0.54)\end{array}$ & $\begin{array}{l}2.13 \\
(0.38)\end{array}$ & $\begin{array}{l}2.20 \\
(0.55)\end{array}$ & $\begin{array}{l}2.14 \\
(0.43)\end{array}$ & $\begin{array}{l}2.23 \\
(0.56)\end{array}$ & $\begin{array}{l}2.16 \\
(0.44)\end{array}$ & $\begin{array}{l}2.21 \\
(0.55)\end{array}$ \\
\hline $\begin{array}{l}\text { Probability of } \\
\text { Unemployment }(\mathrm{m})\end{array}$ & $\begin{array}{l}2.06 \\
(1.04)\end{array}$ & $\begin{array}{l}1.79 \\
(1.15) \\
\end{array}$ & $\begin{array}{l}2.04 \\
(1.01)\end{array}$ & $\begin{array}{l}1.79 \\
(1.14) \\
\end{array}$ & $\begin{array}{l}2.14 \\
(1.07)\end{array}$ & $\begin{array}{l}1.78 \\
(1.13)\end{array}$ & $\begin{array}{l}2.22 \\
(1.13)\end{array}$ & $\begin{array}{l}1.71 \\
(0.55)\end{array}$ \\
\hline Nobs & 266 & 4779 & 594 & 3584 & 840 & 2869 & 647 & 1793 \\
\hline
\end{tabular}

Note: The values within parentheses are standard deviations. 
Table 2

Determinants of Childbirth (East and West Germany, Specification 1)

\begin{tabular}{|c|c|c|c|c|c|c|c|c|}
\hline & \multicolumn{2}{|c|}{$18-45$} & \multicolumn{2}{|c|}{$18-40$} & \multicolumn{2}{|c|}{$18-35$} & \multicolumn{2}{|c|}{$18-30$} \\
\hline & East (2.1) & West (2.1) & East (2.2) & West (2.2) & East (2.3) & West $(2.3)$ & East (2.4) & West (2.4) \\
\hline Age (f) & $\begin{aligned}-0.33 * \\
(0.18)\end{aligned}$ & $\begin{array}{l}0.36^{* * *} \\
(0.03)\end{array}$ & $\begin{array}{l}0.21 \\
(0.33)\end{array}$ & $\begin{array}{l}0.40^{* * *} \\
(0.04)\end{array}$ & $\begin{array}{l}0.24 \\
(0.47)\end{array}$ & $\begin{array}{l}0.36^{* * *} \\
(0.06)\end{array}$ & $\begin{array}{l}1.14 \\
(1.30)\end{array}$ & $\begin{array}{l}0.43^{* * *} \\
(0.14)\end{array}$ \\
\hline Age sq. (f) & $\begin{array}{l}0.00 \\
(\Theta . \odot \odot)\end{array}$ & $\begin{aligned}- & 0.007^{* * *} \\
& (0.0 \odot)\end{aligned}$ & $\begin{aligned} &- 0.00 \\
&(0.0 \odot) \\
&\end{aligned}$ & $\begin{aligned}- & 0.007^{\star * *} \\
& (\odot .0 \odot)\end{aligned}$ & $\begin{aligned} &- 0.00 \\
&(0.0 \odot) \\
&\end{aligned}$ & $\begin{aligned}- & 0.0077^{* * *} \\
& (0.00)\end{aligned}$ & $\begin{aligned} &- 0.02 \\
&(0.02) \\
&\end{aligned}$ & $\begin{aligned}- & 0.008^{* * *} \\
& (\odot . \odot \odot)\end{aligned}$ \\
\hline Household adults & $\begin{aligned} &- 0.53^{\nabla} \\
&(0.37) \\
&\end{aligned}$ & $\begin{aligned}- & 0.03 \\
& (0.10)\end{aligned}$ & $\begin{aligned}- & 5.16^{* *} \\
& (2.53)\end{aligned}$ & $\begin{array}{ll}-0.13 \\
\\
(0.13)\end{array}$ & $\begin{aligned}- & 4.96^{\nabla} \\
& (3.47)\end{aligned}$ & $\begin{array}{l}0.002 \\
(0.17)\end{array}$ & $\begin{array}{l}-5.36 \\
(8.69)\end{array}$ & $\begin{array}{l}-0.12 \\
-(0.27)\end{array}$ \\
\hline Household children & $\begin{aligned}- & 0.16^{\nabla} \\
& (0.11)\end{aligned}$ & $\begin{aligned}- & 0.16^{\star \star *} \\
& (0.02)\end{aligned}$ & $\begin{aligned}- & 0.28^{* *} \\
& (0.13)\end{aligned}$ & $\begin{aligned}- & 0.177^{* \star *} \\
& (0.03)\end{aligned}$ & $\begin{aligned}- & 0.26^{* *} \\
& (0.14)\end{aligned}$ & $\begin{aligned}- & 0.15^{\star * *} \\
& (0.02)\end{aligned}$ & $\begin{aligned}- & 0.38^{* *} \\
& (0.18)\end{aligned}$ & $\begin{aligned}- & 0.066^{* *} \\
& (0.02)\end{aligned}$ \\
\hline Education ( $f$ ) & $\begin{array}{l}0.45^{* *} \\
(0.19)\end{array}$ & $\begin{array}{l}0.17^{* * *} \\
(0.03)\end{array}$ & $\begin{array}{l}0.43^{* *} \\
(0.21)\end{array}$ & $\begin{array}{l}0.17^{* * *} \\
(0.03)\end{array}$ & $\begin{array}{l}0.39^{*} \\
(0.23)\end{array}$ & $\begin{array}{l}0.16^{* * *} \\
(0.03)\end{array}$ & $\begin{array}{l}0.28 \\
(0.38)\end{array}$ & $\begin{array}{l}0.09{ }^{*} \\
(0.04)\end{array}$ \\
\hline Size of home & $\begin{array}{l}0.0 \odot \\
(\Theta . \odot \odot)\end{array}$ & $\begin{array}{c}* * * \\
(\odot . \odot \odot)\end{array}$ & $\begin{array}{l}0.004 \text { * } \\
(0.002)\end{array}$ & $\begin{array}{c}* * * \\
(\odot . \odot \odot)\end{array}$ & $\begin{array}{l}0.0 \odot \\
(\odot . \odot \odot)\end{array}$ & $\begin{array}{r}* * * \\
(\odot . \odot \odot)\end{array}$ & $\begin{array}{l}\Theta . \Theta \odot \\
(\odot . \odot \odot)\end{array}$ & $\begin{array}{l}0.0022^{* * *} \\
(\Theta .00)\end{array}$ \\
\hline $\begin{array}{l}\text { Worries about } \\
\text { finance ( } f \text { ) }\end{array}$ & $\begin{aligned}- & 0.60 \\
& (0.67)\end{aligned}$ & $\begin{aligned}- & 0.08 \\
& (0.15)\end{aligned}$ & $\begin{aligned}- & 1.11^{\nabla} \\
& (0.72)\end{aligned}$ & $\begin{aligned}- & 0.09 \\
& (0.16)\end{aligned}$ & $\begin{aligned}- & 0.84 \\
& (0.75)\end{aligned}$ & $\begin{aligned}- & 0.06 \\
& (0.16)\end{aligned}$ & $\begin{aligned}- & 0.10 \\
& (1.04)\end{aligned}$ & $\begin{array}{l}0.10 \\
(0.19)\end{array}$ \\
\hline $\begin{array}{l}\text { Worries about } \\
\text { finance sq ( } f \text { ) }\end{array}$ & $\begin{array}{l}0.10 \\
(0.18)\end{array}$ & $\begin{array}{l}.02 \\
(\odot .03)\end{array}$ & $\begin{array}{l}0.21 \\
(0.19)\end{array}$ & $\begin{array}{l}.02 \\
(\odot .03)\end{array}$ & $\begin{array}{l}0.16 \\
(0.20)\end{array}$ & $\begin{array}{l}.02 \\
(\odot .03)\end{array}$ & $\begin{array}{l}0.22 \\
(0.28)\end{array}$ & $\begin{array}{l}-0.02 \\
(0.04)\end{array}$ \\
\hline $\begin{array}{l}\text { Probability of } \\
\text { unemployment ( } f \text { ) }\end{array}$ & $\begin{aligned}- & 0.59^{* *} \\
& (0.26)\end{aligned}$ & $\begin{aligned}- & 0.10^{* *} \\
& (0.05)\end{aligned}$ & $\begin{aligned}- & 0.57^{* *} \\
& (0.29)\end{aligned}$ & $\begin{aligned} &- 0.09^{*} \\
&(0.05) \\
&\end{aligned}$ & $\begin{aligned}- & 0.63^{* *} \\
& (0.31)\end{aligned}$ & $\begin{array}{r}-0.09 * \\
(0.05)\end{array}$ & $\begin{array}{r}-0.69 * \\
(0.43)\end{array}$ & $\begin{aligned}- & 0.05 \\
& (0.06)\end{aligned}$ \\
\hline $\begin{array}{l}\text { Probability of } \\
\text { unemployment sq ( } f \text { ) }\end{array}$ & $\begin{array}{l}0.10 * * * \\
(\odot . \odot 3)\end{array}$ & $\begin{array}{l}\Theta . \odot 3^{* * *} \\
(\odot . \odot \odot)\end{array}$ & $\begin{array}{l}0.09 * * \\
(0.04)\end{array}$ & $\begin{array}{l}\odot . \odot 2^{* * *} \\
(\odot . \odot \odot)\end{array}$ & $\begin{array}{l}0.10 \text { ** } \\
(0.04)\end{array}$ & $\begin{array}{l}\Theta .02^{* * *} \\
(\odot .0 \odot)\end{array}$ & $\begin{array}{l}0.10^{*} \\
(0.05)\end{array}$ & $\begin{array}{l}0.022^{* *} \\
(0.01)\end{array}$ \\
\hline Log likelihood & -138.65 & -3820.59 & -123.66 & -3751.84 & -112.78 & -3397.02 & -64.79 & -2220.05 \\
\hline $\mathrm{P}($ Wald chi-sq) & 0.00 & 0.00 & 0.00 & 0.00 & 0.00 & 0.00 & 0.00 & 0.00 \\
\hline Nobs & 2347 & 13025 & 1700 & 11232 & 860 & 8363 & 266 & 4779 \\
\hline Ngroups & 375 & 2397 & 303 & 2130 & 191 & 1800 & 79 & 1339 \\
\hline
\end{tabular}

Note: 1. The values within parentheses are standard errors.

2. ***: $1 \%$ level of significance; **: $5 \%$ level of significance, *: $10 \%$ level of significance, $\nabla: 11-15 \%$ level of significance 
Table 3

Determinants of Childbirth (East and West Germany, Specification 2)

\begin{tabular}{|c|c|c|c|c|c|c|c|c|}
\hline & \multicolumn{2}{|c|}{$18-45$} & \multicolumn{2}{|c|}{$18-40$} & \multicolumn{2}{|c|}{$18-35$} & \multicolumn{2}{|c|}{$18-30$} \\
\hline & East (3.1) & West (3.1) & East (3.2) & West (3.2) & East (3.3) & West (3.3) & East (3.4) & West (3.4) \\
\hline Age (f) & $\begin{array}{r}-0.32 \text { * } \\
(0.18)\end{array}$ & $\begin{array}{l}0.35^{\star * *} \\
(0.03)\end{array}$ & $\begin{array}{l}0.25 \\
(0.33)\end{array}$ & $\begin{array}{l}0.39^{* * *} \\
(0.04)\end{array}$ & $\begin{array}{l}0.29 \\
(0.48)\end{array}$ & $\begin{array}{l}0.33^{\star * *} \\
(0.06)\end{array}$ & $\begin{array}{l}1.15 \\
(1.31)\end{array}$ & $\begin{array}{l}0.42 * * * \\
(0.14)\end{array}$ \\
\hline Age sq. (f) & $\begin{array}{l}0.00 \\
(0.00)\end{array}$ & $\begin{array}{l}-0.0 \odot 7^{\star * *} \\
(\odot . \odot \odot)\end{array}$ & $\begin{aligned} &- 0.00 \\
&(0.0 \odot) \\
&\end{aligned}$ & $\begin{aligned}- & 0.0 \odot 7^{* * *} \\
& (\odot . \odot \odot)\end{aligned}$ & $\begin{aligned}- & 0.00 \\
& (0 . \odot \odot)\end{aligned}$ & $\begin{aligned}- & 0.0066^{* * *} \\
& (0.00)\end{aligned}$ & $\begin{aligned} &- 0.02 \\
&(0.02) \\
&\end{aligned}$ & $\begin{aligned}- & 0.0 \odot 8^{* * *} \\
& (\odot . \odot \odot)\end{aligned}$ \\
\hline Household adults & $\begin{aligned}- & 0.52 \\
& (0.37)\end{aligned}$ & $\begin{aligned}- & 0.02 \\
& (0.10)\end{aligned}$ & $\begin{aligned}- & 5.19^{* *} \\
& (2.57)\end{aligned}$ & $\begin{aligned}- & 0.12 \\
& (0.13)\end{aligned}$ & $\begin{array}{r}-4.97^{\nabla} \\
(3.52)\end{array}$ & $\begin{aligned}- & 0.03 \\
& (0.15)\end{aligned}$ & $\begin{aligned}- & 5.35 \\
& (8.81)\end{aligned}$ & $\begin{array}{l}0.15 \\
(0.27)\end{array}$ \\
\hline Household children & $\begin{aligned}- & 0.16^{\nabla} \\
& (0.11)\end{aligned}$ & $\begin{aligned}- & 0.16 * * * \\
& (0.02)\end{aligned}$ & $\begin{aligned}- & 0.300^{\star *} \\
& (0.13)\end{aligned}$ & $\begin{aligned}- & 0.16^{\star \star *} \\
& (0.02)\end{aligned}$ & $\begin{aligned}- & 0.28 \text { ** } \\
& (0.14)\end{aligned}$ & $\begin{aligned}- & 0.099^{\star \star *} \\
& (\odot .02)\end{aligned}$ & $\begin{aligned}- & 0.45^{* *} \\
& (0.20)\end{aligned}$ & $\begin{aligned}- & 0.055^{* *} \\
& (0.02)\end{aligned}$ \\
\hline Education ( $f$ ) & $\begin{array}{l}0.55^{* *} \\
(0.22)\end{array}$ & $\begin{array}{l}0.14^{* * *} \\
(0.03)\end{array}$ & $\begin{array}{l}0.566^{* *} \\
(0.26)\end{array}$ & $\begin{array}{l}0.14^{* * *} \\
(0.03)\end{array}$ & $\begin{array}{l}0.588^{* *} \\
(0.29)\end{array}$ & $\begin{array}{l}0.13^{* * *} \\
(0.03)\end{array}$ & $\begin{array}{l}0.00 \\
(0.54)\end{array}$ & $\begin{array}{l}0.07{ }^{*} \\
(0.04)\end{array}$ \\
\hline Size of home & $\begin{array}{l}0.00 \\
(0.00)\end{array}$ & $\begin{array}{l}0.0011^{\star * *} \\
(0.00)^{2}\end{array}$ & $\begin{array}{l}0.00^{\nabla} \\
(0.00)\end{array}$ & $\begin{array}{l}0.0011^{* * *} \\
(0.00)\end{array}$ & $\begin{array}{l}\Theta . \Theta \odot \\
(\Theta . \Theta \odot)\end{array}$ & $\begin{array}{l}0.0011^{* * *} \\
(0.00)\end{array}$ & $\begin{array}{l}0.0 \Theta \\
(0.0 \odot)\end{array}$ & $\begin{array}{l}0.002^{* * *} \\
(0.00)\end{array}$ \\
\hline $\begin{array}{l}\text { Worries about } \\
\text { finance ( } f \text { ) }\end{array}$ & $\begin{aligned} &- 0.60 \\
&(0.68) \\
&\end{aligned}$ & $\begin{aligned}- & 0.09 \\
& (0.15)\end{aligned}$ & $\begin{array}{r}-1.11^{\nabla} \\
(0.74)\end{array}$ & $\begin{aligned}- & 0.09 \\
& (0.16)\end{aligned}$ & $\begin{aligned}- & 0.79 \\
& (0.77)\end{aligned}$ & $\begin{aligned}- & 0.05 \\
& (0.15)\end{aligned}$ & $\begin{array}{ll}- & 0.99 \\
& (1.10)\end{array}$ & $\begin{array}{l}0.10 \\
(0.19)\end{array}$ \\
\hline $\begin{array}{l}\text { Worries about } \\
\text { finance sq }(f)\end{array}$ & $\begin{array}{l}0.10 \\
(0.18)\end{array}$ & $\begin{array}{l}0.02 \\
(0.03)\end{array}$ & $\begin{array}{l}0.20 \\
(0.22)\end{array}$ & $\begin{array}{l}0.02 \\
(0.03)\end{array}$ & $\begin{array}{l}0.15 \\
(0.20)\end{array}$ & $\begin{array}{l}0.01 \\
(0.03)\end{array}$ & $\begin{array}{l}0.19 \\
(0.29)\end{array}$ & $\begin{aligned}- & 0.02 \\
& (0.04)\end{aligned}$ \\
\hline $\begin{array}{l}\text { Probability of } \\
\text { unemployment }(f)\end{array}$ & $\begin{aligned} &- 0.57^{* *} \\
&(0.26) \\
&\end{aligned}$ & $\begin{aligned}- & 0.10^{* *} \\
& (0.05)\end{aligned}$ & $\begin{array}{r}-0.53^{*} \\
(0.30) \\
\end{array}$ & $\begin{array}{r}-0.09 \text { * } \\
(0.05) \\
\end{array}$ & $\begin{array}{r}-0.57^{*} \\
(0.32) \\
\end{array}$ & $\begin{array}{r}-0.08 \text { * } \\
(0.05) \\
\end{array}$ & $\begin{aligned} &- 0.71 * \\
&(0.44) \\
&\end{aligned}$ & $\begin{aligned} &- 0.06 \\
&(0.06) \\
&\end{aligned}$ \\
\hline $\begin{array}{l}\text { Probability of } \\
\text { unemployment sq ( } f)\end{array}$ & $\begin{array}{l}0.10^{\star \star \star} \\
(0.03)\end{array}$ & $\begin{array}{l}0.02^{* * *} \\
(0.0 \odot)\end{array}$ & $\begin{array}{l}0.099^{\star *} \\
(0.04)\end{array}$ & $\begin{array}{l}0.02^{\star \star \star} \\
(0.00)\end{array}$ & $\begin{array}{l}0.09^{* *} \\
(0.04)\end{array}$ & $\begin{array}{l}0.02^{* * *} \\
(0.0 \odot)\end{array}$ & $\begin{array}{l}0.11^{\star} \\
(0.06)\end{array}$ & $\begin{array}{l}0.022^{* *} \\
(0.01)\end{array}$ \\
\hline Education $(\mathrm{m})$ & $\begin{array}{l}-0.19 \\
(0.23)\end{array}$ & $\begin{array}{l}0.08^{* *} \\
(0.03)\end{array}$ & $\begin{aligned}- & 0.18 \\
& (0.26)\end{aligned}$ & $\begin{array}{l}0.099^{* *} \\
(0.03)\end{array}$ & $\begin{array}{ll}- & 0.32 \\
& (0.30)\end{array}$ & $\begin{array}{l}0.10^{* * *} \\
(0.03)\end{array}$ & $\begin{array}{l}0.38 \\
(0.53)\end{array}$ & $\begin{array}{l}0.10^{* *} \\
(0.04)\end{array}$ \\
\hline $\begin{array}{l}\text { Probability of } \\
\text { unemployment }(\mathrm{m})\end{array}$ & $\begin{aligned}- & 0.32 \\
& (0.28)\end{aligned}$ & $\begin{aligned}- & 0.002 \\
& (0.05)\end{aligned}$ & $\begin{array}{r}-0.46^{\nabla} \\
(0.31)\end{array}$ & $\begin{aligned}- & 0.006 \\
& (0.06)\end{aligned}$ & $\begin{aligned}- & 0.39 \\
& (0.33)\end{aligned}$ & $\begin{aligned}- & 0.005 \\
& (0.05)\end{aligned}$ & $\begin{aligned}- & 0.37 \\
& (0.47)\end{aligned}$ & $\begin{array}{l}0.09 \\
(0.07)\end{array}$ \\
\hline $\begin{array}{l}\text { Probability of } \\
\text { unemployment sq }(\mathrm{m})\end{array}$ & $\begin{array}{l}0.05 \\
(0.04)\end{array}$ & $\begin{array}{l}0.001 \\
(\odot .0 \odot)\end{array}$ & $\begin{array}{l}0.08^{\nabla} \\
(0.05)\end{array}$ & $\begin{array}{l}0.002 \\
(0.01)\end{array}$ & $\begin{array}{l}0.07 \\
(0.05)\end{array}$ & $\begin{array}{l}0.0 \odot \\
(\Theta .01)\end{array}$ & $\begin{array}{l}0.07 \\
(\odot .09)\end{array}$ & $\begin{array}{l}0.01 \\
(0.01)\end{array}$ \\
\hline Log likelihood & -137.18 & -3817.59 & -121.82 & -3748.50 & -110.73 & -3400.14 & -63.94 & -2216.31 \\
\hline $\mathrm{P}($ Wald chi-sq) & 0.00 & 0.00 & 0.00 & 0.00 & 0.00 & 0.00 & 0.00 & 0.00 \\
\hline Nobs & 2287 & 13025 & 1658 & 11232 & 840 & 8363 & 263 & 4779 \\
\hline Ngroups & 375 & 2397 & 301 & 2130 & 189 & 1800 & 79 & 1339 \\
\hline
\end{tabular}

Note: 1 . The values within parentheses are standard errors.

$2 .{ }^{* *}$ : $1 \%$ level of significance; ${ }^{* *}$ : $5 \%$ level of significance, ${ }^{*}: 10 \%$ level of significance, $\nabla: 11-15 \%$ level of significance 
Table 4

Determinants of Childbirth (West Germany, Specification 2)

\begin{tabular}{|c|c|c|c|c|c|c|c|c|}
\hline & \multicolumn{2}{|c|}{$18-45$} & \multicolumn{2}{|c|}{$18-40$} & \multicolumn{2}{|c|}{$18-35$} & \multicolumn{2}{|c|}{$18-30$} \\
\hline & 1984-92 & $1993-2002$ & $1984-92$ & $1993-2002$ & 1984-92 & 1984-2002 & 1984-92 & $1993-2002$ \\
\hline Age $(f)$ & $\begin{array}{l}0.31^{* * *} \\
(0.05)\end{array}$ & $\begin{array}{l}0.44^{\star \star \star} \\
(0.06)\end{array}$ & $\begin{array}{l}0.33^{\star * *} \\
(0.06)\end{array}$ & $\begin{array}{l}0.500^{\star \star *} \\
(0.06)\end{array}$ & $\begin{array}{l}0.35^{\star \star \star} \\
(0.08)\end{array}$ & $\begin{array}{l}0.41^{\star * *} \\
(0.09)\end{array}$ & $\begin{array}{l}0.499^{\star *} \\
(0.19)\end{array}$ & $\begin{array}{l}0.34^{\nabla} \\
(0.22)\end{array}$ \\
\hline Age sq. (f) & $\begin{aligned}- & 0.0066^{* * *} \\
& (0.00)\end{aligned}$ & $\begin{aligned}- & 0.008^{* \star *} \\
& (0.00)\end{aligned}$ & $\begin{aligned}-0.0066^{* * *} & (0.00)\end{aligned}$ & $\begin{aligned}- & 0.0099^{* * *} \\
& (0.00)\end{aligned}$ & $\begin{aligned}- & 0.0077^{* * *} \\
& (0.00)\end{aligned}$ & $\begin{aligned}- & 0.007^{\star \star *} \\
& (0.0 \odot)\end{aligned}$ & $\begin{aligned}- & 0.011^{\star \star *} \\
& (0.00)\end{aligned}$ & $\begin{aligned}- & 0.006{ }^{\nabla} \\
& (\odot . \odot \odot)\end{aligned}$ \\
\hline Household adults & $\begin{array}{l}0.06 \\
(0.13)\end{array}$ & $\begin{aligned}- & 0.05 \\
& (0.16)\end{aligned}$ & $\begin{array}{l}-0.02 \\
\\
(0.16)\end{array}$ & $\begin{array}{ll}- & 0.25 \\
& (0.24)\end{array}$ & $\begin{array}{l}0.15 \\
(0.19)\end{array}$ & $\begin{array}{l}-0.45 \\
\\
(0.37)\end{array}$ & $\begin{array}{ll}- & 0.21 \\
& (0.35)\end{array}$ & $\begin{array}{ll}- & 0.09 \\
& (0.43)\end{array}$ \\
\hline Household children & $\begin{aligned}- & 0.12^{* * *} \\
& (0.03)\end{aligned}$ & $\begin{aligned}- & 0.16^{* \star *} \\
& (0.03)\end{aligned}$ & $\begin{aligned}- & 0.12^{* * *} \\
& (0.03)\end{aligned}$ & $\begin{aligned}- & 0.16^{* \star *} \\
& (0.03)\end{aligned}$ & $\begin{aligned}- & 0.08^{* \star \star} \\
& (0.03)\end{aligned}$ & $\begin{aligned}- & 0.15^{* * *} \\
& (0.03)\end{aligned}$ & $\begin{aligned}- & 0.06 \nabla \\
& (0.04)\end{aligned}$ & $\begin{aligned}- & 0.06^{\nabla} \\
& (0.04)\end{aligned}$ \\
\hline Education ( $f$ ) & $\begin{array}{l}0.21^{* * *} \\
(0.05)\end{array}$ & $\begin{array}{l}0.099^{*} \\
(0.04)\end{array}$ & $\begin{array}{l}0.21^{* * *} \\
(0.05)\end{array}$ & $\begin{array}{l}0.099^{* *} \\
(0.05)\end{array}$ & $\begin{array}{l}0.19^{* * *} \\
(0.04)\end{array}$ & $\begin{array}{l}0.07 \\
(\odot .05)\end{array}$ & $\begin{array}{l}0.16^{\star * *} \\
(0.05)\end{array}$ & $\begin{aligned}- & 0.01 \\
& (0.06)\end{aligned}$ \\
\hline Size of home & $\begin{array}{l}0.0022^{* * *} \\
(0.05)\end{array}$ & $\begin{array}{l}0.0011^{* *} \\
(0.00)\end{array}$ & $\begin{array}{l}0.002{ }^{*} \\
(0.02)\end{array}$ & $\begin{array}{l}0.0011^{* *} \\
(0.00)\end{array}$ & $\begin{array}{l}0.002^{* * *} \\
(0.00)\end{array}$ & $\begin{array}{l}0.001^{* *} \\
(0.0 \odot)\end{array}$ & $\begin{array}{l}0.0044^{* \star *} \\
(0.0 \odot)^{*}\end{array}$ & $\begin{array}{l}0.001{ }^{* *} \\
(0.00)\end{array}$ \\
\hline $\begin{array}{l}\text { Worries about } \\
\text { finance }(f)\end{array}$ & $\begin{aligned}- & 0.28 \\
& (0.23)\end{aligned}$ & $\begin{array}{l}0.08 \\
(0.22)\end{array}$ & $\begin{aligned}- & 0.30 \\
& (0.23)\end{aligned}$ & $\begin{array}{l}0.08 \\
(0.23)\end{array}$ & $\begin{aligned}- & 0.23 \\
& (0.23)\end{aligned}$ & $\begin{array}{l}0.09 \\
(0.24)\end{array}$ & $\begin{aligned}- & 0.19 \\
& (0.27)\end{aligned}$ & $\begin{array}{l}0.32 \\
(0.29)\end{array}$ \\
\hline $\begin{array}{l}\text { Worries about } \\
\text { finance sq ( } f)\end{array}$ & $\begin{array}{l}0.06 \\
(0.05)\end{array}$ & $\begin{array}{ll}- & 0.01 \\
& (0.05)\end{array}$ & $\begin{array}{l}0.06 \\
(0.05)\end{array}$ & $\begin{array}{ll}- & 0.01 \\
& (0.05)\end{array}$ & $\begin{array}{l}0.05 \\
(0.05)\end{array}$ & $\begin{aligned}- & 0.01 \\
& (0.05)\end{aligned}$ & $\begin{array}{l}0.03 \\
(0.06)\end{array}$ & $\begin{aligned}- & 0.06 \\
& (0.06)\end{aligned}$ \\
\hline $\begin{array}{l}\text { Probability of } \\
\text { unemployment }(f)\end{array}$ & $\begin{aligned}- & 0.06 \\
& (0.07)\end{aligned}$ & $\begin{aligned}-0.13^{*} & (0.07)\end{aligned}$ & $\begin{aligned}- & 0.05 \\
& (0.07)\end{aligned}$ & $\begin{aligned}- & 0.14^{*} \\
& (0.08)\end{aligned}$ & $\begin{aligned}- & 0.06 \\
& (0.07)\end{aligned}$ & $\begin{aligned}- & 0.12^{\nabla} \\
& (0.05)\end{aligned}$ & $\begin{aligned}- & 0.05 \\
& (0.09)\end{aligned}$ & $\begin{aligned}- & 0.06 \\
& (0.10)\end{aligned}$ \\
\hline $\begin{array}{l}\text { Probability of } \\
\text { unemployment sq ( } f)\end{array}$ & $\begin{array}{l}0.022^{* \star} \\
(0.01)\end{array}$ & $\begin{array}{l}0.03^{\star *} \\
(0.01)\end{array}$ & $\begin{array}{l}0.022^{* \star} \\
(0.01)\end{array}$ & $\begin{array}{l}0.03^{* *} \\
(0.01)\end{array}$ & $\begin{array}{l}0.022^{* *} \\
(0.01)\end{array}$ & $\begin{array}{l}0.02 \text { ** } \\
(0.01)\end{array}$ & $\begin{array}{l}0.02^{\star} \\
(0.01)\end{array}$ & $\begin{array}{l}0.01 \\
(0.01)\end{array}$ \\
\hline Education $(\mathrm{m})$ & $\begin{array}{l}0.04 \\
(0.05)\end{array}$ & $\begin{array}{l}0.10 \text { ** } \\
(0.04)\end{array}$ & $\begin{array}{l}0.04 \\
(0.05)\end{array}$ & $\begin{array}{l}0.111^{* *} \\
(0.04)\end{array}$ & $\begin{array}{l}0.06 \\
(0.05)\end{array}$ & $\begin{array}{l}0.12 \text { ** } \\
(0.05)\end{array}$ & $\begin{array}{l}0.03 \\
(0.06)\end{array}$ & $\begin{array}{l}0.14^{* *} \\
(0.06)\end{array}$ \\
\hline $\begin{array}{l}\text { Probability of } \\
\text { unemployment }(\mathrm{m})\end{array}$ & $\begin{aligned}- & 0.12 \\
& (0.08)\end{aligned}$ & $\begin{array}{l}0.05 \\
(0.08)\end{array}$ & $\begin{aligned}- & 0.11 \\
& (0.08)\end{aligned}$ & $\begin{array}{l}0.04 \\
(0.08)\end{array}$ & $\begin{aligned}- & 0.11 \\
& (0.08)\end{aligned}$ & $\begin{array}{l}0.05 \\
(0.09)\end{array}$ & $\begin{array}{l}0.08 \\
(0.10)\end{array}$ & $\begin{array}{l}0.08 \\
(0.11)\end{array}$ \\
\hline $\begin{array}{l}\text { Probability of } \\
\text { unemployment } \mathrm{sq}(\mathrm{m})\end{array}$ & $\begin{array}{l}0.01 \\
(0.01)\end{array}$ & $\begin{aligned} &- 0.003 \\
&(0.01) \\
&\end{aligned}$ & $\begin{array}{l}0.01 \\
(0.01)\end{array}$ & $\begin{aligned}- & 0.0 \odot \\
& (\odot .01)\end{aligned}$ & $\begin{array}{l}0.01 \\
(0.01)\end{array}$ & $\begin{aligned} &- 0.004 \\
&(0.01) \\
&\end{aligned}$ & $\begin{aligned}- & 0.01 \\
& (0.01)\end{aligned}$ & $\begin{aligned} &- 0.006 \\
&(0.01) \\
&\end{aligned}$ \\
\hline Log likelihood & -1704.71 & -1896.06 & -1683.71 & -1853.40 & -1549.97 & -1656.56 & -1103.86 & -1001.19 \\
\hline P(Wald chi-sq) & 0.00 & 0.00 & 0.00 & 0.00 & 0.00 & 0.00 & 0.00 & 0.00 \\
\hline Nobs & 5669 & 6602 & 4910 & 5665 & 3818 & 4063 & 2355 & 2175 \\
\hline Ngroups & 1757 & 1576 & 1522 & 1394 & 1249 & 1107 & 891 & 747 \\
\hline
\end{tabular}

Note: 1 . The values within parentheses are standard errors.

2. ***: $1 \%$ level of significance; **: $5 \%$ level of significance, *: $10 \%$ level of significance, $\nabla: 11-15 \%$ level of significance 


\section{Figure 1}

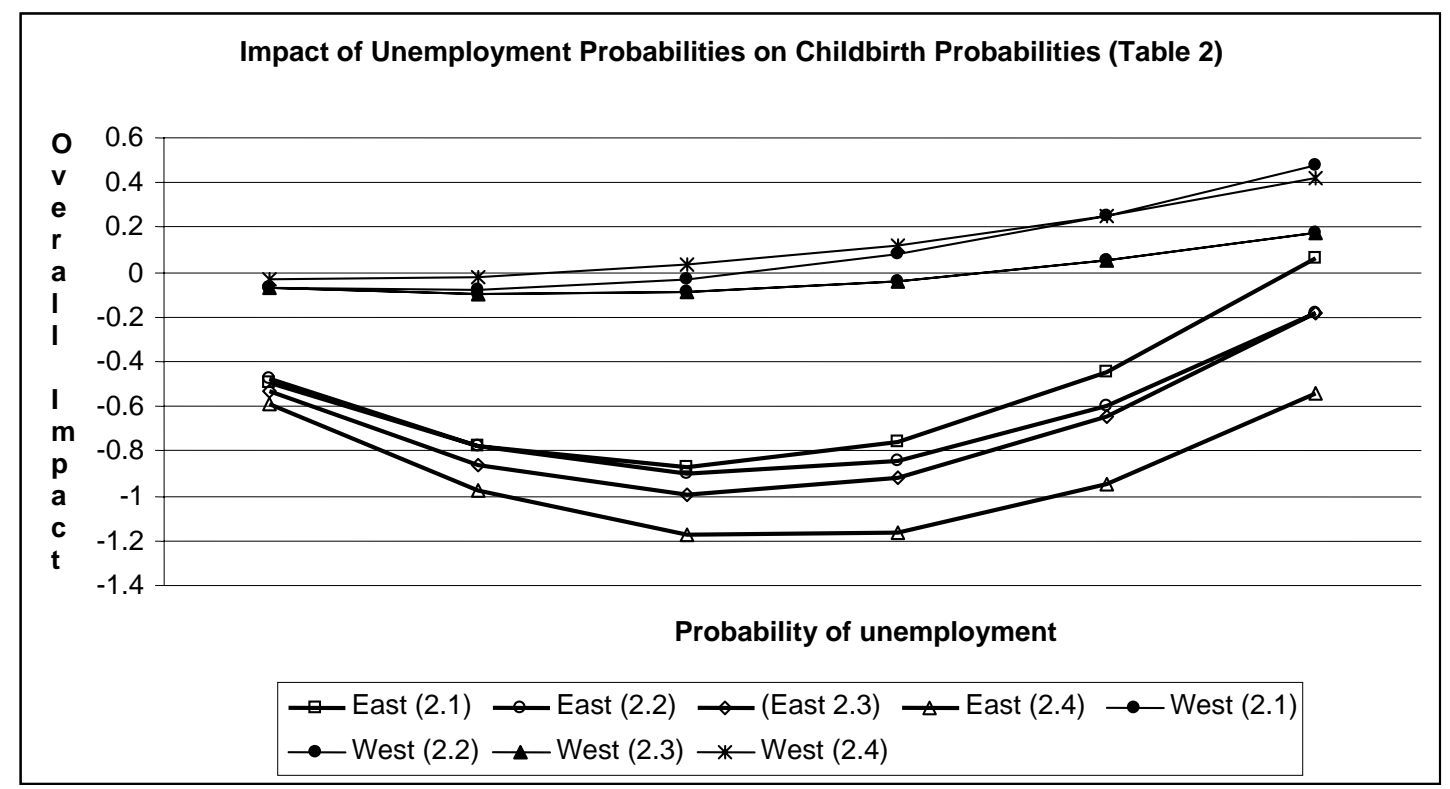




\section{Figure 2}

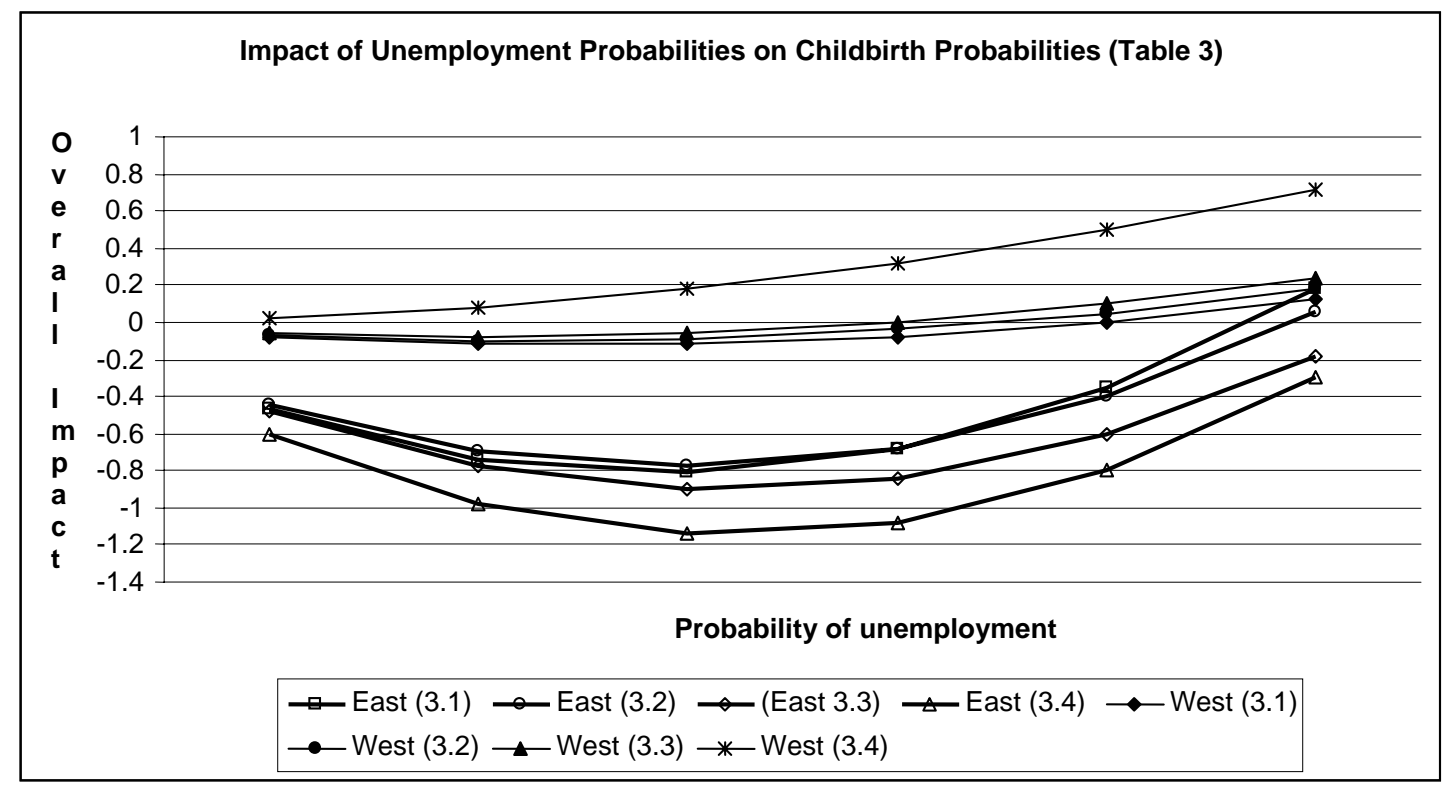




\section{Endnotes}

${ }^{1}$ It is easily seen, therefore, that we can talk about the probability of (un)employment and employment uncertainty in an interchangeable manner, as we sometimes do later in the paper. Later on, however, we show that the mapping is not one-to one

${ }^{2}$ While in principle comparability would be served by presenting the descriptive statistics for the probability of unemployment and other measures for West Germany separately for the pre- and post-1992 periods, in the interest of space since there were no important differences in these variables between the two periods for Western Germany, for this region the data pertain to the whole period. The descriptive statistics for the separate periods are available on request.

${ }^{3}$ Neither does it refute the postponement hypothesis. See, especially Sobotka (2004).

${ }^{4}$ The GSOEP questionnaire provides two different measures with which one can generate an ordered set of the probabilities of unemployment. If a person is employed, she is asked how confident she is about her job security. The possible responses are very concerned, somewhat concerned and not concerned at all. If the person is unemployed at the time of the survey, on the other hand, and is looking for employment, she is asked how confident she is about finding a new job. The possible responses are easy, difficult and almost impossible. We use this range of responses to construct a 6-point score for each respondent representing her probability of being unemployed in the foreseeable future. In addition, we assume that if a person is not a participant in the labor force at the time of the survey, her likelihood of finding a job is low, and hence we automatically assign to her the highest score of 6 . In keeping with our earlier discussion, it is easy to see that the uncertainty related to employment is highest for scores of 3 or 4, and lowest for the scores of 1 and 6.

${ }^{5}$ By 1995, 36 percent of the East German women who were employed prior to reunification lost employment, the corresponding figure for East German men being 23 percent.

${ }^{6}$ We have outlined in footnote 3 the measure for the uncertainty score with respect to employment. The uncertainty score about a household's financial status is more limited in its scope. The GSOEP questionnaire asks each respondent how confident she is about the household's financial prospects. The possible responses are very concerned, somewhat concerned and not concerned at all. Using the responses to this question, we have created a 3-point measure of the uncertainty score for a household's financial status that is increasing in the level of uncertainty.

${ }^{7}$ Space can have a significant negative impact on household formation, and thereby affect decisions to bear child adversely. It is considered to be among the main reasons for low total fertility rates in Italy and Spain (Lesthaeghe and Moors, 2000).

${ }^{8}$ In Figures 1-2, the 6-point unemployment probability score is on the horizontal axis. Using the coefficient estimates, we plot the overall marginal effects for each level of uncertainty along the vertical axis. The labeling should be interpreted as follows: In Figure 1, the locus of points labeled East (2.1) refer to the overall marginal effects generated using column 2.1 of Table 2 which reports the coefficient estimates of the East German women in the 18-45 age group, for the 1992-2002 period. The other loci of points in Figures 1-2, as captured by the curves, can be similarly interpreted.

${ }^{9}$ According to Bonin and Euwals (2001), prior to reunification, the labor force participation rate of East German women was nearly 80 percent. This rate of participation was comparable only to those in Scandinavian countries, and much higher than the labor force participation rate of women in West Germany where the negative impact of laws governing maternity leave and income taxation of couples is well established (Strøm and Wagenhals, 1991; Spahn et al., 1994). This trend persisted after the reunification, despite a significant decline in employment opportunities facing East German 
woman in the aftermath of reunification. In 2000, 72 percent of the women in East Germany were labor force participants, the corresponding figure for West Germany being 62 percent.

${ }^{10}$ The overall (marginal) impact of employment uncertainty is $-1.27(=-0.69 \times 3+0.10 \times 9)$ when the level of uncertainty is 3 . When this uncertainty level rises to 4 , the overall (marginal) impact changes to $-1.16(=-0.69 \times 4+0.10 \times 16)$. The impact of a unity change in employment uncertainty, therefore, is -0.09 . The other numbers reported in this paragraph can be similarly obtained. 


\section{DAVIDSON INSTITUTE WORKING PAPER SERIES - Most Recent Papers}

The entire Working Paper Series may be downloaded free of charge at: www.wdi.bus.umich.edu

CURRENT AS OF 8/18/05

\begin{tabular}{|c|c|c|}
\hline Publication & Authors & Date \\
\hline $\begin{array}{l}\text { No. 788: Does Economic Uncertainty Affect the Decision to Bear } \\
\text { Children? Evidence from East and West Germany }\end{array}$ & $\begin{array}{l}\text { Sumon Kumar Bhaumik and } \\
\text { Jeffrey B. Nugent }\end{array}$ & Aug. 2005 \\
\hline $\begin{array}{l}\text { No. 787: Economic Reform and Changing Patterns of Labor Force } \\
\text { Participation in Urban and Rural China }\end{array}$ & $\begin{array}{l}\text { Margaret Maurer-Fazio and } \\
\text { James W. Hughes }\end{array}$ & Aug. 2005 \\
\hline $\begin{array}{l}\text { No. 786: The Determinants of Asset Stripping: Theory and Evidence } \\
\text { From the Transition Economies }\end{array}$ & $\begin{array}{l}\text { Nauro F. Campos and Francesco } \\
\text { Giovannoni }\end{array}$ & Aug. 2005 \\
\hline $\begin{array}{l}\text { No. 785: How to Catch Foreign Fish? FDI and Privatization in EU } \\
\text { Accession Countries }\end{array}$ & $\begin{array}{l}\text { Bruno Merlevede and Koen } \\
\text { Schoors }\end{array}$ & Aug. 2005 \\
\hline $\begin{array}{l}\text { No. 784: Does the World Bank have any impact on human development } \\
\text { of the poorest countries? Some preliminary evidence from Africa }\end{array}$ & Sumon Kumar Bhaumik & Aug. 2005 \\
\hline $\begin{array}{l}\text { No. 783: Comparative social capital: Networks of entrepreneurs and } \\
\text { investors in China and Russia }\end{array}$ & Bat Batjargal & July 2005 \\
\hline $\begin{array}{l}\text { No. 782: Exchange Rate Regimes, Foreign Exchange Volatility and } \\
\text { Export Performance in Central and Eastern Europe: Just Another Blur } \\
\text { Project? }\end{array}$ & $\begin{array}{l}\text { Balázs Égert and Amalia } \\
\text { Morales-Zumaquero }\end{array}$ & July 2005 \\
\hline $\begin{array}{l}\text { No. 781: Equilibrium Exchange Rate in the Czech Republic: How Good } \\
\text { is the Czech BEER? }\end{array}$ & ázs Égert & July 2005 \\
\hline $\begin{array}{l}\text { No. 780: Autonomy and Performance of Foreign Subsidiaries in five } \\
\text { Transition Countries }\end{array}$ & $\begin{array}{l}\text { Urmas Varblane, Katrin Männik, } \\
\text { and Helena Hannula }\end{array}$ & July 2005 \\
\hline $\begin{array}{l}\text { No. 779: The Political Economy of Industrial Policy in China: The Case } \\
\text { of Aircraft Manufacturing }\end{array}$ & Andrea Goldstein & July 2005 \\
\hline $\begin{array}{l}\text { No. 778: Bank Supervision Russian style: Rules versus Enforcement } \\
\text { and Tacit Objectives }\end{array}$ & $\begin{array}{l}\text { Sophie Claeys, Gleb Lanine and } \\
\text { Koen Schoors }\end{array}$ & June 2005 \\
\hline No. 777: Labor Market Trends and Institutions in Belarus & $\begin{array}{l}\text { Zuzana Brixiova and Vera } \\
\text { Volchok }\end{array}$ & June 2005 \\
\hline $\begin{array}{l}\text { No. 776: Can Vietnam Achieve One of its Millennium Development } \\
\text { Goals? An analysis of schooling dropouts of children }\end{array}$ & $\begin{array}{l}\text { Vo Tri Thanh And Trinh Quang } \\
\text { Long }\end{array}$ & June 2005 \\
\hline $\begin{array}{l}\text { No. 775: Is The Link Between Reforms And Growth Spurious? A } \\
\text { Comment }\end{array}$ & Tomasz Mickiewicz & May 2005 \\
\hline $\begin{array}{l}\text { No. 774: The Risk Aversion of Banks in Emerging Credit markets: } \\
\text { Evidence from India }\end{array}$ & $\begin{array}{l}\text { Sumon Kumar Bhaumik and } \\
\text { Jenifer Piesse }\end{array}$ & 2005 \\
\hline $\begin{array}{l}\text { No. 773: Organized Labor and Restructuring: Coal Mines in the Czech } \\
\text { Republic and Romania }\end{array}$ & $\begin{array}{l}\text { Jan Bruha, Delia Ionascu, and } \\
\text { Byeongju Jeong }\end{array}$ & May 2005 \\
\hline $\begin{array}{l}\text { No. 772: Is Political Risk Company-Specific? The Market Side of the } \\
\text { Yukos Affair }\end{array}$ & $\begin{array}{l}\text { Alexei Goriaev and Konstantin } \\
\text { Sonin }\end{array}$ & May 2005 \\
\hline $\begin{array}{l}\text { No. 771: Non-Linear Exchange Rate Dynamics in Target Zones: A } \\
\text { Bumpy Road Towards A Honeymoon }\end{array}$ & $\begin{array}{l}\text { Jesús Crespo-Cuaresma, Balázs } \\
\text { Égert, and Ronald MacDonald }\end{array}$ & May 2005 \\
\hline $\begin{array}{l}\text { No. 770: Equilibrium Exchange Rates in Southeastern Europe, Russia, } \\
\text { Ukraine and Turkey: Healthy or (Dutch) Diseased? }\end{array}$ & Balázs Égert & May 2005 \\
\hline $\begin{array}{l}\text { No. 769: Equilibrium Exchange Rates in Central and Eastern Europe: A } \\
\text { Meta-Regression Analysis }\end{array}$ & Balázs Égert and László Halpern & May 2005 \\
\hline $\begin{array}{l}\text { No. 768: Testing for inflation convergence between the Euro Zone } \\
\text { and its CEE partners }\end{array}$ & Imed Drine and Christophe Rault & Apr. 2005 \\
\hline $\begin{array}{l}\text { No. 767: Labor Mobility during Transition: Evidence from the Czech } \\
\text { Republic }\end{array}$ & Jan Fidrmuc & Apr. 2005 \\
\hline $\begin{array}{l}\text { No. 766: Formation of social capital in Central and Eastern Europe: } \\
\text { Understanding the gap vis-à-vis developed countries }\end{array}$ & Jan Fidrmuc and Klal & Apr. 2005 \\
\hline $\begin{array}{l}\text { No. 765: Do Regional Integration Agreements Increase Business-Cycle } \\
\text { Convergence? Evidence From APEC and NAFTA }\end{array}$ & $\begin{array}{l}\text { Viviana Fernandez and Ali M. } \\
\text { Kutan }\end{array}$ & Apr. 2005 \\
\hline $\begin{array}{l}\text { No. 764: State Regulations, Job Search and Wage Bargaining: A Study } \\
\text { in the Economics of the Informal Sector }\end{array}$ & Maxim Bouev & Apr. 2005 \\
\hline $\begin{array}{l}\text { No. 763: The Feldstein-Horioka Puzzle Revisited: An “European- } \\
\text { Regional” Perspective }\end{array}$ & $\begin{array}{l}\text { Jérôme Hericourt and Mathilde } \\
\text { Maurel }\end{array}$ & Apr. 2005 \\
\hline
\end{tabular}

